\title{
Financial Distress and its Predicting Factors among Iranian Cancer Patients
}

\author{
Abazar Fathollahzade', Azad Rahmani2*, Abbas Dadashzadeh ${ }^{1}$, Akram \\ Gahramanian $^{1}$, Ali Esfahani², Leila Javanganji² ${ }^{2}$ Leila Nabiolahi ${ }^{1}$
}

\begin{abstract}
Background: Financial distress due to the cost of cancer treatments is prevalent among cancer patients. Identifying the level of financial distress and its affecting factors has an important role in providing supportive services. Accordingly, the aims of this study were to determine these parameters among Iranian cancer patients. Materials and Methods: This descriptive-correlational study was undertaken among 262 cancer patients admitted to both private and public hospitals in East Azerbaijan province, Iran. The financial distress/financial well being scale was used to determine financial distress. The data were analyzed using SPSS software using descriptive and inferential statistics (multiple linear regression). Results: Among the 262 cancer patients, 57.3\% were male and their mean age was 47.0 years. The mean score for financial distress was $4.12(2.01)$. The final regression model demonstrated that the independent variables (predictors) of income less than living expenses, income equal to living expenses, having an employed spouse in governmental job and living with parents, with regression coefficients of $\mathbf{- 1 . 0 2 9}, \mathbf{- 0 . 5 1 5}, \mathbf{0 . 1 9 8}$, and $\mathbf{0 . 0 9 6}$, respectively, were predictors of financial distress among cancer patients. These variables accounted for $50 \%$ of changes in variance of financial distress. Conclusions: Iranian cancer patients have moderate to high levels of financial distress. Considering policies for managing direct and indirect costs of cancer treatments must be followed.
\end{abstract}

Keywords: Cancer - financial distress - financial burden - Iran

Asian Pac J Cancer Prev, 16 (4), 1621-1625

\section{Introduction}

Cancer is one of the main health problems in the world. According to global statistics it has been estimated that 12.7 million new cancer cases and approximately 7.6 million cancer deaths were recorded in 2008. In this regard, $56 \%$ of new cancer cases and $64 \%$ of the deaths occurred in developing countries (Jemal et al., 2011). Also, it is predicted that cancer death will increase to 13.1 million by 2030 (WHO, 2014). Also, cancer is a major health problem in Iran and according to the Iranian ministry of health and medical education cancer is the third most common cause of death in Iran after cardiovascular diseases and road traffic accidents (Mousavi et al., 2009).

In many societies, cancer is still accompanied by a lot of negative emotions such as pain, suffering and forthcoming death. In addition, changes to appearance due to cancer and its treatments, such as hair loss, may result in patients' social isolation (Kearney, 2012; Afrooz et al., 2014). In fact, despite the increasing survival probability of cancer patients in recent decades, most of these patients experience fear and confusion after the diagnosis. Also, cancer patients face many different challenges in all phases of diagnosis, treatment and rehabilitation (Spagnola et al., 2003; Abdollahzadeh et al., 2014). In many studies, anxiety (Roy-Byrne et al., 2008), depression (DiMatteo et al., 2000) and stress (NCCN, 2010) have been reported as major complications experience by cancer patients.

High costs of diagnosis and treatment of cancer is one of the factors that can cause great stress for cancer patients and their families (Kim et al., 2003; Mostert et al., 2012; Chang et al., 2013; Nair et al., 2013). Financial distress can results from two main sources including short-term or permanent loss of job and long-lasting / costly cancer treatments (Longo et al., 2006). In this regard, the results of a study showed that $50 \%$ of financial burden of cancer was related to loss of income, $40 \%$ was due to medical expenses paid by the patients and $9 \%$ was associated to the indirect costs of cancer (Arozullah et al., 2004).

The increasing number of cancer survivors in recent years attracts more attentions towards the economic burden of cancer diagnosis/treatment (Steiner et al., 2004). For example, in the United States cancer is the second costly disease after heart disease. However, medical and 
insurance organizations only pays one-third of the cancer cost. Studies have shown that financial burden of cancer is the main cause of patients' tensions after their concerns regarding treatment options and disease prognosis (Brown et al., 2001).

Direct and indirect costs of cancer treatment caused financial difficulties for many cancer patients and their caregivers in some Western countries (Hayman et al., 2001). However, in developing countries the economic conditions are more complicated. In most of these countries, governments undertake little amounts of the cancer costs and most of direct and indirect costs must to pay by the patients and families (Zaidi et al., 2012). In an extensive literature review there was no study which examined the level of financial distress in Iranian cancer patients. Knowledge regarding such distress is crucial for planning supportive care programs for cancer patients and their families. Accordingly, the aim of this study was to determine the level of financial distress in Iranian cancer patients. In addition, it sought to recognize demographic factors which can predict such distress.

\section{Materials and Methods}

This descriptive-correlational study was conducted in both educational and private hospitals in Tabriz, the capital of East Azerbaijan Province in northeast of Iran. The study population included all patients who were referred to the centers during the study period and met the following criteria: (a) having confirmed cancer diagnosis; (b) be at least 18 years old; (c) willing to participate in the study; and (d) at least 3 months passed since they were aware of exact diagnosis. The sample size $(\mathrm{n}=250)$ was calculated based on a pilot study. Considering a $10 \%$ attrition rate, 275 eligible patients were invited to participate in the study using convenience sampling. Finally, 262 cancer patients accepted to be enrolled (acceptance rate $=95 \%$ ).

Data collection was composed of two main parts. The first part was a checklist that investigated the demographic and disease related characteristics of patients based on patients' self-report or their medical records. The second part included the financial distress/financial well being scale developed by O'Neill et al in 2006 (O'Neill et al., 2006). This scale has 8 items classified according to a ten-point Likert scale ranging from 1 (highest financial distress) to 10 (without financial distress). Finally, the sum of each patients scores in all items divided by 8 which represent patients' financial distress.

For using in present study, the questionnaire was translated into Persian and then back translated. The scale accuracy and fluency confirmed by two translator expert in both Persian and English languages. The scales face and content validity were assessed and verified by the expert panel constituted ten faculty members affiliated to Tabriz university of medical sciences, Tabriz, Iran. Some minor changes were applied according to expert recommendations. The final version of the questionnaire was tested for reliability in a pilot study involving 25 cancer patients. Cronbach-Alpha coefficient value for financial distress/financial well being scale was 0.92 .

Before the data collection, the study proposal was approved by the regional ethics committee at Tabriz university of medical sciences. Then, hospital managers' agreements were obtained for data collections. Next, one of researchers was referred to both hospitals. Patients

Table 1. Demographic Characteristics of Participants.

\begin{tabular}{|c|c|c|c|}
\hline Variable & Groups & Frequency & Percent \\
\hline \multirow[t]{2}{*}{ Sex } & Male & 150 & 57.3 \\
\hline & Female & 112 & 42.7 \\
\hline \multirow[t]{4}{*}{ Education } & Illiterate & 39 & 14.9 \\
\hline & Primary & 113 & 43.1 \\
\hline & Diploma & 67 & 25.6 \\
\hline & University & 43 & 16.4 \\
\hline \multirow[t]{4}{*}{ Job } & Unemployed & 41 & 15.6 \\
\hline & Handworker & 93 & 35.5 \\
\hline & Governmental staff & aff 49 & 18.7 \\
\hline & Housewife & 79 & 30.2 \\
\hline \multirow[t]{3}{*}{ Marital status } & Married & 222 & 84.7 \\
\hline & Single & 32 & 12.2 \\
\hline & Widowldivorced & 8 & 3.1 \\
\hline \multirow[t]{3}{*}{ Financial status } & Income $>$ expense & 18 & 6.9 \\
\hline & Income $=$ expense & 87 & 33.2 \\
\hline & Income<expense & 157 & 59.9 \\
\hline \multirow[t]{2}{*}{ Place of living } & City & 194 & 74 \\
\hline & Village & 68 & 26 \\
\hline \multirow[t]{5}{*}{ Type of cancer } & Blood & 118 & 45 \\
\hline & Gastro-intestinal & 68 & 26 \\
\hline & Lung & 9 & 3.4 \\
\hline & Breast & 20 & 7.6 \\
\hline & Other & 47 & 17.9 \\
\hline \multirow[t]{2}{*}{ History of chemotherapy } & Yes & 257 & 98.1 \\
\hline & No & 5 & 1.9 \\
\hline \multirow[t]{2}{*}{ History of radiotherapy } & Yes & 12 & 4.6 \\
\hline & No & 250 & 95.4 \\
\hline \multirow[t]{2}{*}{ History of surgery } & Yes & 80 & 30.5 \\
\hline & No & 182 & 69.5 \\
\hline \multirow[t]{5}{*}{ Education of spouse } & Unmarried & 37 & 14.1 \\
\hline & Illiterate & 48 & 18.3 \\
\hline & Primary & 104 & 39.7 \\
\hline & Diploma & 48 & 18.3 \\
\hline & University & 25 & 9.5 \\
\hline \multirow[t]{5}{*}{ Job of spouse } & Unmarried & 37 & 14.1 \\
\hline & Unemployed & 13 & 5 \\
\hline & Handworker & 59 & 22.5 \\
\hline & Governmental staff & ff 38 & 14.5 \\
\hline & Housewife & 115 & 43.9 \\
\hline \multicolumn{4}{|c|}{ Time passed since awareness of diagnosis/months } \\
\hline & 3 to 6 & 97 & 37 \\
\hline & 6 to 12 & 77 & 29.4 \\
\hline & Over than 12 & 88 & 33.6 \\
\hline
\end{tabular}

Table 2. Participants Response to Items of Financial Distress/Financial Well Being Scale.

\begin{tabular}{|c|c|c|}
\hline Questions & Mean & $\mathrm{SD}$ \\
\hline Feeling about level of financial stress today & 4.17 & 2.2 \\
\hline $\begin{array}{l}\text { Mark satisfaction with present financial situation } \\
\text { (on stair steps from } 0 \text { to } 10 \text { ) }\end{array}$ & 4.5 & 2.42 \\
\hline Feeling about current financial situation & 3.64 & 2.07 \\
\hline $\begin{array}{l}\text { Worries about being able to meet normal } \\
\text { monthly living expense }\end{array}$ & 3.7 & 2.1 \\
\hline $\begin{array}{l}\text { Confidence to find or borrow about } \$ 1,000 \\
\text { for a financial emergency }\end{array}$ & 3.8 & 2.5 \\
\hline Limiting recreational activities because can't afford & d 4.75 & 2.66 \\
\hline Frequency of living paycheck to paycheck & 4.28 & 2.77 \\
\hline Perceived stress about personal finances in general & 4.13 & 2.25 \\
\hline Total financial distress score & 4.12 & 2.01 \\
\hline
\end{tabular}


Table 3. Predictors of Financial Distress Among Cancer Patients.

\begin{tabular}{|c|c|c|c|c|c|c|c|}
\hline \multirow[t]{2}{*}{ predictors } & \multirow[t]{2}{*}{ B } & \multirow[t]{2}{*}{ SE B } & \multirow[t]{2}{*}{$\mathrm{b}$} & \multirow[t]{2}{*}{$\mathrm{t}$} & \multirow[t]{2}{*}{ sig } & \multicolumn{2}{|c|}{$95 \%$ Confidence Interval for B } \\
\hline & & & & & & Lower & Upper \\
\hline (Constant) & 0.128 & 0.337 & & 21.128 & 0.001 & 6.464 & 7.793 \\
\hline Income less than costs & -4.215 & 0.352 & -1.029 & -11.967 & 0.001 & -4.908 & -3.521 \\
\hline Income equal to costs & -2.196 & 0.368 & -0.515 & -5.962 & 0.001 & -2.921 & -1.471 \\
\hline Spouse employed in governmental jobs & 1.129 & 0.262 & 0.198 & 4.305 & 0.001 & 0.613 & 1.645 \\
\hline Living with father and mother & 0.525 & 0.245 & 0.096 & 2.148 & 0.033 & 0.044 & 1.007 \\
\hline
\end{tabular}

who met criteria for the study were identified and all eligible patients were informed and invited to participate. All patients who participated in the study gave informed consent according to ethic committee guideline. Willing patients were asked to participate in a private interview for data collection. Data collection lasted from April to June 2014.

Data were analyzed using SPSS version 15. Descriptive statistics such as frequency, percentage, mean and standard deviation were used to describe the demographic/diseaserelated characteristics and financial distresses. Multiple linear regression (Forward method) was used to determine predictors of the financial distress. P value lower than 0.05 was considered as meaningful.

\section{Results}

The mean of participants' ages was 47.0 years $(\mathrm{SD}=16.22$ years). Some other demographic and disease related characteristics are summarized in Table 1.

The results also showed that the mean score for financial distress was 4.12 (2.01). Table 2 shows the participants' responses to all the items of financial distress/ financial well being scale.

The final regression model demonstrated that the independent variables (predictors) of income less than living expense, income equal to living expense, having an employed spouse in governmental jobs and living with parents could convey the variations of dependent variable (financial distress) in patients with cancer. These variables were accounted for $50 \%$ of changes in variance of financial distress (adjusted R square $=0.507 ; \mathrm{F}=68.056 ; \mathrm{p}=0.001$ ).

Predictors of financial distress in participants are shown in Table 3. As shown in this table, having financial conditions of income less than living expense and income equal to living expense causes a decrease in financial distress scores by 1.029 and 0.515 times respectively, compared to that of income more than living expense. Also, having an employed spouse in a governmental jobs was associated with a 0.198 times increase in the financial distress scores compared to other employment conditions of spouses in married patients. In addition, living with parents increased the financial distress scores 0.096 times, compared to that of living with spouse and children. It should be noted that the higher scores in financial distress/financial well being scale indicates lower levels of financial distress.

\section{Discussion}

According to extensive literature review, this is one of the first studies which investigatedfinancial distress and its predictors among Iranian cancer patients.

The study findings showed cancer patients had moderate to high levels of financial distress. Financial distress is a common experience in most of cancer patients in the world and also had been reported in developed countries. For example, Van Hoose et al. (2014) found that financial distress is one of the most important types of distress in American cancer patients (VanHoose et al., 2014). Other study also reported $31 \%$ of American cancer patients rated their financial situation as poor (Gupta et al., 2007).

The financial distress among cancer patients is a prevailing phenomenon. The findings of a study by Arozullah. (2004) in the United States revealed financial distress even is prevalent among insured cancer patients (Arozullah et al., 2004). Such tensions also reported in some European countries. Cohen et al. (2003) reported parents of children with cancer were paid most of treatment costs themselves. Paying these costs by parents obliged them to relinquish other expenses, such as recreation activities (Cohn et al., 2003). Similarly, findings of studies in India (Pandey et al., 2006), South Korea (Yi et al., 2014) and southeast Asian nations (Kimman et al., 2012) also indicate high level of financial distress in cancer patients. Therefore, it is obvious that the process of cancer diagnosis/treatment apart from the financial burden to healthcare system also cause financial difficulties for patients and their families. In result, a large percentage of household incomes are expended for health services. For example, findings of a study by Sulku and Bernard. (2012) in Turkey showed that a large percentage of family income spent for medical treatment (Sulku and Bernard, 2012). Accordingly, it should be considered that financial distress directly affects the various dimensions of quality of life in cancer patients (Gupta et al., 2007; Rogers et al., 2012). So, effective strategies should be implemented to reduce cancer patients' financial distress.

This study also showed that patients' financial distress increased with decrease in their incomes. This inevitable finding suggests that patients' incomes directly affect their financial distress. In this regard, previous studies also showed unemployment problems caused by the illness is among the important predictors of financial distress among cancer patients and their families (Heath et al., 2006; Rogers et al., 2012). This is also supported by other studies (Ell et al., 2008; Markman and Luce., 2010; Chino et al., 2014).

According to the study findings, majority of patients who lived with their parents were single and reported financial distress less than married ones. This finding is incongruent with a previous study in India who reported higher levels of financial distress among unmarried cancer 
patients (Pandey et al., 2006). This finding is sensible in Iranian context as single people are usually living with their parents and in most cases are not responsible for supplying their family expenditure. So, apart from treatment costs married patients should also provide other family expenses and then are experiencing more financial distress.

Another study finding was that patients who had an employed spouse in a governmental jobs reported lower financial distress compared to other employment conditions of spouse in married patients. The rational for this finding can be explained by non-governmental and governmental job differences in Iran. Employees who work in governmental organizations can use medical leave during disease periods and also receive their monthly salaries. Such circumstances no longer exist for most of the people working in non-governmental organizations and they always are worrying about losing their jobs. Similar to our findings, some previous studies reported high level of financial distress among single-parent families who faced with cancer diagnosis (Emanuel et al., 1999; Rogers et al., 2012)

The study findings can be used for designing and implanting supportive care programs for cancer patients. Findings showed moderate to high levels of financial stress among participants. So, this requires special considerations of Iranian health care system regarding financial difficulties of cancer patients. In this regard, supplementary insurance coverage for cancer treatments and introducing patients to related charities can be helpful. Such consideration should be more concentrate on married patients and those with lower incomes.

Despite the strength of this study, it also has some limitations. First, a sample of patients admitted into two medical centers in East Azerbaijan province in northwestern of Iran cannot represent the overall state of financial distress among Iranian cancer patients. Next, in some cases, patients might not disclose their real financial situation and reported it worse than the truth. However, this limitation resolved to a large extent by explaining the objectives of the study. In relation to future research, replicating such studies in other Iranian regions is required. In addition, the effects of financial stress on different aspects of cancer patients' life requires further studies.

\section{Acknowledgements}

This is a report of a database from thesis entitled "financial distress and its predicting factors among Iranian cancer patients" approved by Tabriz university of medical sciences. The authors wish to acknowledge all of the patients, whose contribution enabled the production of this article.

\section{References}

Abdollahzadeh F, et al (2014). Un-met supportive care needs of Iranian breast cancer patients. Asian Pac J Cancer Prev, 15, 3933-8.

Afrooz R, et al (2014). The nature of hope among Iranian cancer patients. Asian Pac J Cancer Prev, 15, 9307-12.

Arozullah AM, et al (2004). The financial burden of cancer: estimates from a study of insured women with breast cancer. J Support Oncol, 2, 271-8.

Brown ML, Lipscomb J, Snyder C (2001). The burden of illness of cancer: Economic cost and quality of life. Annu Rev Public health, 22, 91-113.

Chang YJ, Kwon YC, Lee WJ, Do YR, Seok LK, et al (2013). Burdens, needs and satisfaction of terminal cancer patients and their caregivers. Asian Pac J Cancer Prev, 14, 209-16.

Chino F, Peppercorn J, Taylor DH Jr, Lu Y, Samsa G, et al (2014). Self-reported financial burden and satisfaction with care among patients with cancer. Oncologist, 19, 414-20.

Cohn RJ, Goodenough B, Foreman T, Suneson J (2003). Hidden financial costs in treatment for childhood cancer: an Australian study of lifestyle implications for families absorbing out-of-pocket expenses. J Pediatr Hemato Oncol, 25, 854-63.

DiMatteo MR, Lepper HS, Croghan TW (2000). Depression is a risk factor for noncompliance with medical treatment: meta-analysis of the effects of anxiety and depression on patient adherence. Arch Intern Med, 160, 2101-7.

Ell K, Xie B, Wells A, Nedjat-Haiem F, Lee PJ, et al (2008). Economic stress among low-income women with cancer. Cancer, 112, 616-25.

Emanuel EJ, et al (1999). Assistance from family members, friends, paid care givers and volunteers in the care of terminally ill patients. $N$ England $J$ Med, 341, 956-63.

Gupta D, Lis CG, Grutsch JF (2007). Perceived cancer-related financial difficulty: implications for patient satisfaction with quality of life in advanced cancer. Support Care Cancer, 15, 1051-6.

Hayman JA, et al (2001). Estimating the cost of informal caregiving for elderly patients with cancer. J Clin Oncol, 19, 3219-25.

Heath JA, Lintuuran RM, Rigguto G, Tikotlian N, McCarthy M (2006). Childhood cancer: its impact and financial costs for Australian families. Pediatr Hemato Oncol, 23, 439-48.

Jemal A, Bray F, Center MM, Ferlay J, Ward E, et al (2011). Global cancer statistics. CA Cancer J Clin, 61, 69-90.

Kearney N, Giulio P (2012). Nursing cancer practice: a textbook for the specialist nurse. Elsevier Harcourt Brace.

Kim J, Garman ET, Sorhaindo B (2003). Relationships among credit counseling clients' financial well-being, financial behaviors, financial stressor events and health. Financial Counseling Planning, 14, 75-87.

Kimman M, et al (2012). Socioeconomic impact of cancer in member countries of the association of Southeast Asian nations (ASEAN): the ACTION study protocol. Asian Pac $J$ Cancer Prev, 13, 421-5.

Longo CJ, Fitch M, Deber RB, Williams AP (2006). Financial and family burden associated with cancer treatment in Ontario, Canada. Support Care Cancer, 14, 1077-85.

Markman M, Luce R (2010). Impact of the cost of cancer treatment: an internet-based survey.J Oncol Pract, 6, 69-73.

Mostert S, et al (2012). Socio-economic status plays important roles in childhood cancer treatment outcome in Indonesia. Asian Pac J Cancer Prev, 13, 6491-6.

Mousavi SM, Gouya MM, Ramazani R, Davanlou M,Hajsadeghi $\mathrm{N}$, et al (2009). Cancer incidence and mortality in Iran. Ann Oncol, 20, 556-63.

Nair KS, Raj S, Tiwari VK, Piang LK (2013). Cost of treatment for cancer: experiences of patients in public hospitals in India. Asian Pac J Cancer Prev, 14, 5049-54.

NCCN (The National Comperehensive Cancer Network) (2010). Distress management clinical practice guidelines in oncology, version 1. Available at: www.ncen.org/ 
professionals/physician_gls/f_guidelines.asp\#supportive.

O’Neill B, Prawitz AD, Sorhaindo B, Kim J, Garman ET (2006).

Changes in health, negative financial events and financial distress/financial well-being for debt management program clients. Journal of Financial Counseling and Planning, 17, 34-45.

Pandey M, Thomas BC, Ramdas K, NandaMohan V (2006). Factors influencing distress in Indian cancer patients. Psychooncology, 15, 547-50.

Rogers S, Harvey-Woodworth C, Lowe D (2012). Patients' perspective of financial benefits following head and neck cancer in Merseyside and Cheshire. Br J Oral and Maxillo Surg, 50, 404-9.

Roy-Byrne PP, Davidson KW, Kessler RC, Asmundson GJ, Goodwin RD, et al (2008). Anxiety disorders and comorbid medical illness. Gen Hosp Psychiatry, 6, 467-85.

Spagnola S, Zabora J, BrintzenhofeSzoc K, et al (2003). The satisfaction with life domains scale for breast cancer (SLDSBC). Breast J, 9, 463-71.

Steiner JF, Cavender TA, Main DS, Bradley CJ (2004). Assessing the impact of cancer on work outcomes. Cancer, 101, 1703-11.

Sulku SN, Bernard DM (2012). Financial burden of health care expenditures: Turkey. Iran J Public Health, 41, 48-64.

VanHoose L, Black LL, Doty K, Sabata D, Twumasi-Ankrah P, et al (2014). An analysis of the distress thermometer problem list and distress in patients with cancer. Support Care Cancer, 16, (Epub ahead of print)

WHO (2014). Programmes and projects, Cancer. In, http://www. who.int/cancer/en

Yi M, Park K, Park EY (2014). Psychosocial needs of lowincome people with cancer in Korea. Eur J Oncol Nurs, 18, 549-56.

Zaidi AA, Ansari TZ, Khan A (2012). The financial burden of cancer: Estimates from patients undergoing cancer care in a tertiary care hospital. Int J Equity Health, 11, 60. 